\title{
PADRONIZAÇÃO E AVALIAÇÃo DA SEN SIBILIDADE E ESPECIFICIDADE DE UM TESTE ELISA INDIRETO PARA O DIAGNÓSTICO DA BRUCELOSE BOVINA UTILIZANDO COMO ANTÍGENO A CEPA DE B abortusINATIVADA
}

\author{
Standardization and evaluation of sensitivity and specificity of an \\ indirect E L ISA test for the diagnostic of bovine brucellosis using \\ as antigen a strain of inactivated B. abortus
}

\section{Vitor Borges Putini ${ }^{\mathrm{a}}$, Rodrigo Bonfim Cruz ${ }^{\mathrm{a}}$, Gabriela dos Santos Santana ${ }^{\mathrm{a}}$, Jaqueline Santos Jorge ${ }^{\mathrm{a}}$, Diógenis Lima da Silva ${ }^{\mathrm{b}}$, Margareth Mourac, Renato Carminatid, Robson Bahia Cerqueira ${ }^{\mathrm{e}}$}

\footnotetext{
a Discente do Curso de Medicina Veterinária da Unime, Lauro de Freitas, BA - Brasil, e-mail: robsonba@ gmail.com

b Auxiliar de Saúdedo Laboratório deD oenças Infecciosas (INIME/ LAD I), Salvador, BA - Brasil, e-mail: diogenisls@ hotmail.com

c Médica Veterinária do Centro de D esenvolvimento da Pecuária da Universidade Federal da Bahia, Salvador, BA - Brasil, e-mail: robsonba@gmail.com

` Médico Veterinário, Professor orientador e responsável pelo Laboratório de D oenças Infecciosas, Mestre e D outorando em Imunologia da Unime, Lauro de Freitas, BA - Brasil, e-mail: rcarminat@ gmail.com

e Médico Veterinário, Professor de Microbiologia da Unime, Lauro de Freitas, BA - Brasil, e-mail: robsonba@ gmail.com
}

\begin{abstract}
Resumo
A brucelose é uma enfermidade infecciosa de caráter crônico que acomete os animais domésticos gerando grandes prejuízos à pecuária, além de ser uma grave zoonose ocupacional e de origem alimentar. Isso fez com que alguns países adotassem medidas para sua erradicação ou diminuição da sua ocorrência através de métodos de diagnóstico confiáveis, de fácil execução além de recursos para sua realização. 0 presente trabalho teve como objetivo padronizar um Ensaio Imunoenzimático Indireto para o diagnóstico da brucelose bovina, utilizando como antígeno a linhagem Brucalla abortus inativada, na concentração de 4,5\% produzido para prova lenta em tubo. D esse modo, foram selecionadas 91 amostras de soro de vacas procedentes de fazendas produtoras de leite, submetidas ao Ensaio Imunoenzimático Indireto, das quais 45 foram reagentes ao AAT e 46 não reagentes ao teste referido. As 45 amostras reagentes ao AAT, 35 foram também reagente ao ELISA indireto. Todas as amostras não reagentes ao teste de triagem foram negativas ao ELISA indireto. Logo, observou-se que o Ensaio Imunoenzimático Indireto apresentou sensibilidade de 77,8\% e especificidade de 100\%, mostrando ainda uma concordância de 89\%.
\end{abstract}

Palavras-chave: Teste Elisa; Brucelose bovina; Bruœlla abortus; D iagnóstico. 


\begin{abstract}
Brucellosis is a chronic infectious disease that affects domestic animals generating large losses to livestock besides being a serious occupational zoonosis and of nutritional origin. These problems have driven some countries to adopt measures aiming to eradicate them or to decrease its occurrence through reliable methods of diagnosis and easy addition of resources for its implementation. The present research work aimed to standardize an indirect immunoenzymatic test for the diagnosis of bovine brucellosis, as the antigen lineage Brucella abortus 1119-3 heat inactivated producing evidence of slowing in tube at the concentration of $4,5 \%$. In this way, a total of 91 sera samples were selected from cows from milk production farms, all of them subjected to the indirect immunoenzymatic test. From this total, 45 samples were reagents to the AAT and 46 were not. From the 45 reagent samples, 35 were also reagent to the indirect ELISA. All the non reagent samples were also negative for the indirect ELISA. It has been then observed that the indirect immunoenzymatic test displayed a total sensitivity of $77,8 \%$ and a specificity of $100 \%$ showing also an agreement as high as $89 \%$.
\end{abstract}

Keywords: Elisa test; Ovine brucelosis; Brucella abortus; Diagnostic.

\title{
INTRODUÇÃO
}

A brucelose é uma enfermidade infecciosa grave que acomete os animais domésticos, caracterizada por aborto e infertilidade, acometendo bovinos, bubalinos, suínos, ovinos, caprinos e equinos, gerando grandes prejuízos à pecuária, além de ser uma grave zoonose ocupacional e de origem alimentar (FREITAS et al., 2000). Enfermidade cosmopolita descrita na maioria dos países, principalmente os mais pobres, porém, algumas nações conseguiram reduzir a sua prevalência ou mesmo erradicá-la (MATHIAS; MEIRELLES; BUCHALA, 2007). Ortolani et al. (1987) relataram que no Brasil a brucelose é considerada como uma enfermidade endêmica, sendo encontrada em todo território nacional. $\mathrm{O}$ agente etiológico da brucelose bovina é a Brucella abortus, que durante sua evolução desenvolveu mecanismos para conviver com seus hospedeiros, particularmente os bovinos, permitindo sua sobrevivência no organismo hospedeiro por períodos prolongados, favorecendo a disseminação do patógeno na população (SILVA et al., 2005). D e acordo com a O rganização Mundial de Saúde (OMS), atualmente, a verdadeira frequência de casos de brucelose poderá ser cinco ou mais vezes superior do que os números oficiais em consequência do subdiagnóstico e a subdeclaração "obrigatória", mesmo nos países desenvolvidos (PESSEG UEIRO; BARATA; CORREIA, 2003). Molnar et al. (2000) demonstraram como principais características da doença, aborto, mortalidade perinatal, nascimento de bezerros pequenos e fracos, queda na produção leiteira e infertilidade, ressaltando seu impacto na saúde pública. A maioria dos países desenvolvidos adotou medidas destinadas à sua erradicação, que iniciaram há mais de 20 anos, enquanto em outros, como a França e os EUA, mantêm-na controlada. A produtividade dos rebanhos está diretamente relacionada com a sanidade, 0 combate à brucelose é de extrema importância para evitar maiores prejuízos ao rebanho, e deve ser realizado de forma eficaz através do conhecimento do agente causador, seu local de atuação e sua frequência de ocorrência, o que leva a uma dependência de métodos de identificação dos animais ou rebanhos infectados (RIBEIRO et al., 2003). O Programa Nacional de Controle e Erradicação da Brucelose e Tuberculose recomenda o teste do Rosa de Bengala (antígeno acidificado tamponado [AAT]) como teste de triagem, no caso de soros positivos, podendo ser confirmados pela combinação da prova de soroaglutinação lenta com a prova do 2-mercaptoetanol ou pela prova de fixação de complemento (MATHIAS; MEIRELLES; BUCHALA, 2007). 0 presente trabalho teve como objetivo padronizar e avaliar a sensibilidade e especificidade de um teste Elisa indireto para o diagnóstico da brucelose bovina utilizando como antígeno cepa de B. abortus inativada. 
Padronização e avaliação da sensibilidade e especificidade de um teste ELISA indireto para 0 diagnóstico da brucelose bovina utilizada como antígeno a cepa de B. abortus inativada

\section{MATERIAL E MÉTODO}

\section{Amostras}

Foram utilizadas 91 amostras de soro de vacas da raça girolando procedentes de fazendas produtoras de leite. Quarenta e cinco animais foram vacinados, com inoculação realizada na idade tradicional (3-8 meses) e que no momento da coleta apresentavam-se com idade entre três e cinco anos, com reação para os testes Antígeno A cidificado Tamponado, Soro A glutinação Lenta e 2-Mercaptoetanol. Q uarenta e seis animais apresentavam-se com idade superior a 24 meses, também vacinados na idade tradicional, mas não reagentes para os testes AAT, SAL e 2-ME. Esses soros foram cedidos gentilmente pela Clinilab (Clínica e Laboratório de Reprodução) e Laboratório de Zoonoses da Universidade Federal da Bahia, contendo em cada alíquota aproximadamente 1,5 ml.

\section{Ensaio imunoenzimático indireto}

0 antígeno utilizado foi o mesmo que se utiliza para a prova de soroaglutinação lenta, com concentração de massa bacteriana de 4,5\%, sem corante, padronizado a partir da cepa 1119-3 de B rucella abortus, inativada pelo calor, produzido pelo Instituto de Tecnologia do Paraná (TECPAR). Partida: 001/ 06 e data de fabricação: Fev/ 06. A padronização utilizada foi na diluição de 1:50. Realizou-se uma placa com as seguintes diluições, antígeno puro, 1:50, 1:100, 1:200, 1:500 e observou-se que o melhor resultado encontrado foi 1:50 (FREY; D I CANZIO ; ZURAKOWSK I, 1998). O protocolo foi padronizado no Laboratório de D oenças Infecciosas da Unime. Primeiramente 0 antígeno foi diluído em tampão carbonato bicarbonato 0,05 M pH 9,6 para sensibilização da placa; com uma micropipeta acrescentouse $100 \mathrm{ml}$ do antígeno em cada poço da placa com 96 poços colocada em câmara úmida, mantida "over night" à temperatura entre 4 a 8으. D epois de retirada da geladeira a placa foi lavada duas vezes com PBST e iniciou-se o bloqueio com leite desnatado a $5 \%$, adicionado $200 \mathrm{ml}$ por poço da placa que foi levada dentro de uma câmara úmida para estufa a 37으 por duas horas. D epois de retirada da estufa, a placa foi lavada uma vez com PBS-T. Procedeu-se a diluição do soro na concentração de 1:10.000 seguindo o protocolo seguinte: foram colocados 45 tubos ependorf, devidamente identificados na galeria e, após diluição do leite desnatado a $1 \%$ em 50ml de PBS-T, foi transferida $1 \mathrm{ml}$ dessa diluição para cada ependorf. Acrescentou-se em seguida $10 \mathrm{ml}$ de cada soro conforme mapa de identificação, num total de 45 amostras. Após essa operação foram retirados 50ml dessa diluição e colocados em duplicata em cada poço da placa que foi levada para a estufa a 37으 por 1 hora. D epois de retirada da estufa, a placa foi lavada cinco vezes com PBS-T e, em seguida, diluiu-se 10ml do conjugado anti-IgG caprino em 10ml de PBS-T em diluição 1:10.000, transferindo-se 50ml dela em cada poço da placa que foi levada para a estufa a 37으 por uma hora. Após isso, a placa foi lavada cinco vezes com PBS-T. Preparou-se a solução reveladora, na qual se diluiu $4 \mathrm{ml}$ de água oxigenada, $4 \mathrm{mg}$ de OPD (ortosenilenodiamino) em 10 $\mathrm{ml}$ de tampão citrato pH 5,1. Acrescentou-se, então, 50ml dessa diluição em cada poço da placa que foi guardada sem exposição da luz para revelação entre 15 e 20 minutos. Após esse tempo, interrompeuse a reação com ácido sulfúrico 4N e realizou-se a leitura da placa em filtro de $490 \mathrm{~nm}$.

\section{Antígeno acidificado tamponado}

O antígeno utilizado foi produzido no Instituto de Tecnologia do Paraná (TECPAR) e adquirido pelo órgão de Defesa Agropecuário da Bahia (ADAB). A linhagem utilizada foi a Brucella abortus 1119-3, na concentração celular de 4\%, inativada pelo calor e corada pela Rosa de Bengala. Partida: 002/ 05 e data de fabricação: Mar/ 05. 0 protocolo foi realizado conforme recomendação do Programa Nacional de Controle e Erradicação da Brucelose e Tuberculose bovina (PNCE BT) organizado pelo Ministério da Agricultura Pecuária e Abastecimento (MAPA). O s soros assim como o antígeno, foram retirados respectivamente do congelador e da geladeira, colocados à temperatura ambiente por aproximadamente 30 minutos. Em seguida, as amostras de soro foram organizadas em galeria, 
identificadas em uma ficha de controle interno do Laboratório de D oenças Infecciosas, homogeneizado e, com uma micropipeta, retirados $30 \mu \mathrm{l}$ e colocado, com um ângulo de $45^{\circ}$, em placa de vidro. 0 antígeno foi colocado ao lado na mesma quantidade, sem que tivesse contato com o soro. Após homogeneização, foram realizadas, com a ajuda de um bastão, movimentos circulares 30 vezes/ minuto aproximadamente, durante 4 minutos. A leitura foi feita com o auxílio de caixa de fundo escuro e a identificação da reação foi observada pela presença ou não de grumos.

\section{Prova do 2-Mercaptoetanol (2-ME)}

0 antígeno utilizado foi o mesmo que se utiliza para a prova de soroaglutinação lenta, com concentração de massa bacteriana de 4,5\%, sem corante, padronizado a partir da cepa 1119-3 de Brucella abortus inativada pelo calor, produzido pelo Instituto de Tecnologia do Paraná (TECPAR). Partida: 001/ 06 e data de fabricação: Fev/ 06. O protocolo foi realizado conforme recomendação do Programa Nacional de Controle e Erradicação da Brucelose e Tuberculose Bovina (PNCEBT) organizado pelo Ministério da Agricultura (MAPA). Os soros reagentes, na prova do AAT, foram identificados, homogeneizados e submetidos à prova do 2-Mercapto etanol e Soro A glutinação Lenta. Com a pipeta de Bang, os soros foram colocados em tubos identificados com as respectivas numerações, cada amostra possuindo 4 tubos, com distribuição de 0,08 $\mathrm{ml}, 0,04 \mathrm{ml}, 0,02 \mathrm{ml}, 0,01 \mathrm{ml}$ do soro. O 2-ME foi diluído a uma concentração de $0,78 \%$ em solução salina a $0,85 \%$, e colocado $1 \mathrm{ml}$ em cada tubo contando 30 minutos de repouso e, em seguida, foi adicionado $1 \mathrm{ml}$ do antígeno diluído em solução salina a 2\%. Após 48 horas foi realizada a leitura, com o teste controle positivo e negativo, e analisada as precipitações com formação de grumos e classificados como reagentes de acordo com as diluições 1:25, 1:50, 1:100, 1:200.

\section{Prova da soroaglutinação lenta (SAL)}

0 antígeno utilizado apresenta concentração de massa bacteriana de 4,5\%, sem corante, padronizado a partir da cepa 1119-3 de Brucella abortus inativada pelo calor, produzido pelo Instituto de Tecnologia do Paraná (TECPAR). Partida: 001/ 06 e data de fabricação: Fev/ 06. 0 protocolo foi realizado conforme recomendação do Programa de Controle da Brucelose eT uberculose bovinas organizado pelo Ministério da Agricultura. Os soros reagentes na prova do AAT foram identificados, homogeneizados e submetidos à prova do SAL. Com a pipeta de Bang, os soros foram colocados em tubos identificados com as respectivas numerações, cada amostra possuindo 4 tubos, com distribuição de 0,08 ml, 0,04 ml, 0,02 ml, 0,01ml. 0 fenol foi diluído a 0,5\% em solução salina a 0,85\% e 0 antígeno diluído a 1\% na solução salina fenicada. Em seguida, foi adicionado $2 \mathrm{ml} \mathrm{em}$ cada tubo. Após 48 horas foi realizada a leitura, com o teste controle positivo e negativo, e analisada as precipitações com formação de grumos e classificadas como reagentes de acordo com as diluições 1:25, 1:50, 1:100, 1:200.

\section{Estudo Estatístico}

0 "cut-off" calculado através da média da D ensidade Ótica dos animais não reagentes +3 desvio padrão (FREY et al., 1998). A concordância entre os dois testes foi calculada por meio da fórmula citada por MATHIAS et al. (1998).

Positivos em ambos os testes + negativos em ambos os testes $\mathrm{x} 100$

Total de soros testados 
Padronização e avaliação da sensibilidade e especificidade de um teste ELISA indireto para 0 diagnóstico da brucelose bovina utilizada como antígeno a cepa de B. abortus inativada

\section{Determinação da sensibilidade e especificidade}

A fórmula utilizada foi baseada no estudo de Mathias et al. (1998) conforme representação abaixo:

$$
\text { Sensibilidade }=\frac{\text { Doentes } \text { det ectados peloteste }}{\text { Total de doentes testados }} 100
$$

$$
\text { Especificidade }=\frac{\text { Sãos negativos aoteste }}{\text { Total de sãos testados }} 100
$$

Para determinar a sensibilidade e especificidade relativa do teste ELISA indireto, foram considerados doentes os animais positivos no teste Rosa de Bengala e no ELISA indireto, e sadios os animais negativos nessas duas provas.

$$
\begin{aligned}
& \text { Sensibilidade }=\frac{35}{45} 100=77,8 \% \\
& \text { Especificidade }=\frac{46}{46} 100=100 \%
\end{aligned}
$$

\section{RESULTADOS}

D as 91 amostras analisadas neste experimento todas foram submetidas ao teste do Antígeno A cidificado Tamponado, no qual se obteve 46 amostras não reagentes e 45 reagentes, Figura 1.

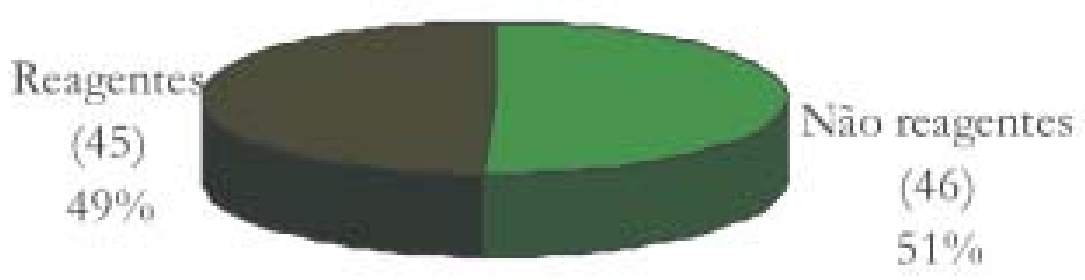

FIG URA 1 - Amostras de soro bovino submetidos ao teste do AAT

Figure 1 - Samples of bovine serum subjected to the test of the A A T 
Todas as amostras foram submetidas ao teste do 2-mercaptoetanol, no qual se verificou que as 45 amostras reagentes ao AAT apresentaram titulação a partir de 1:25 e as 46 não reagentes ao referido teste também foram não reagentes ao 2-ME, obedecendo a tabela de animais com idade superior a 24 meses preconizada pelo PNCEBT (Programa Nacional de Controle e Erradicação da Brucelose e Tuberculose).

As 91 amostras foram submetidas ao teste ELISA indireto, observando-se que das 45 reagentes ao teste AAT, 35 apresentaram valores de Abs acima do "cut-off" $(0,122)$ com Absorbância variando entre 0,125 a 0,314, representado na Figura 2, onde a concordância entre os testes foi de 89\%, a sensibilidade de $77,8 \%$ e especificidade de $100 \%$. Nas amostras não reagentes ao AAT foram encontrado valor de D.O. de 0,078 a 0,122, representado na Figura 3.

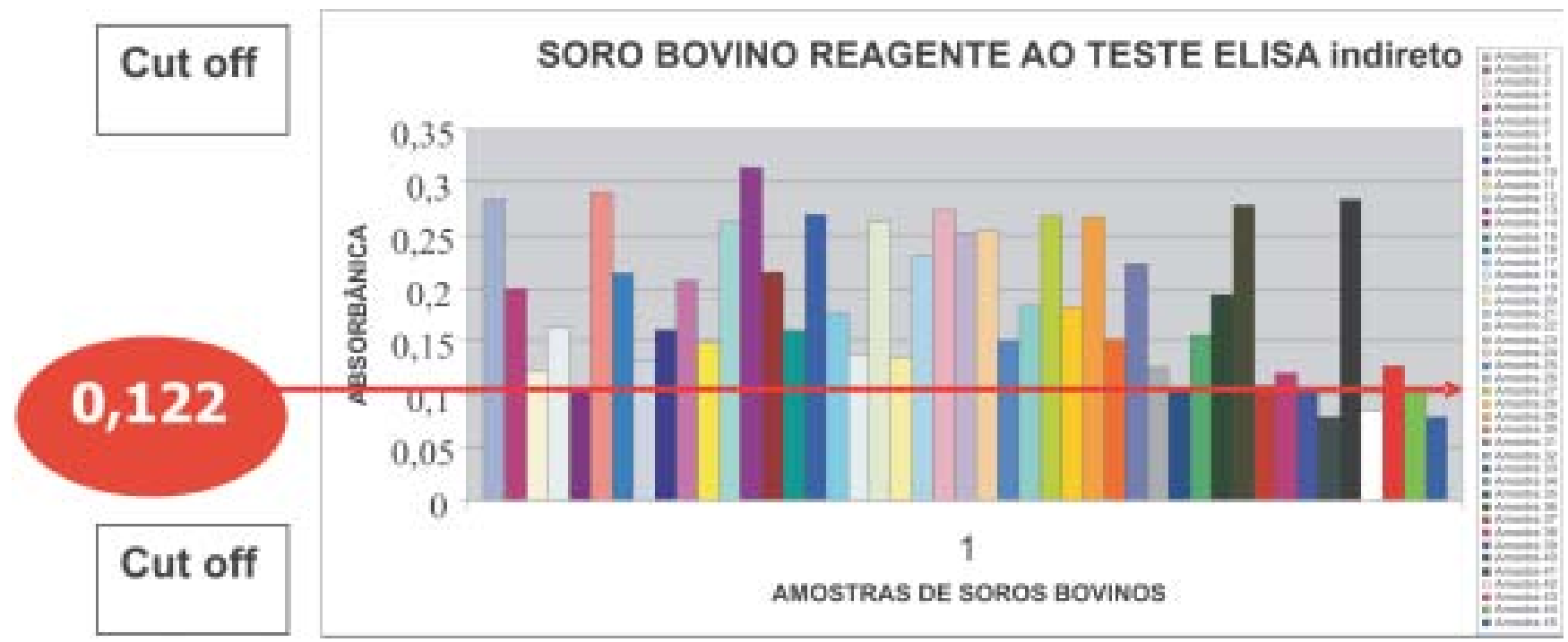

FIG URA 2 - Valores de absorbância de soro de bovinos reagentes ao Teste ELISA indireto Figure $2-V$ alues of absorbance of bovine serum reacting to the indirect $\mathrm{E}$ L ISA test

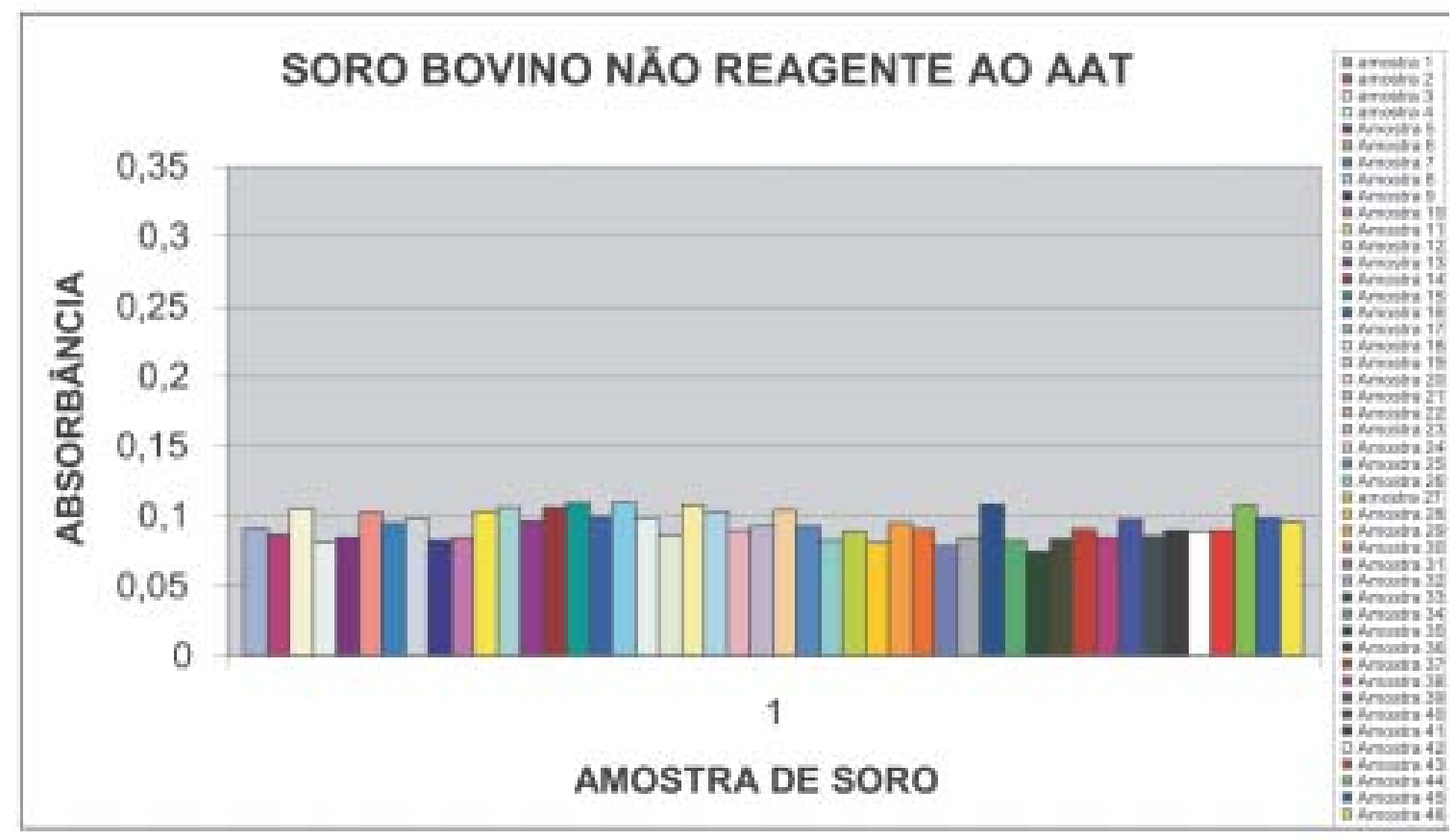

FIGURA 3 - Valores de absorbância de soros bovinos não reagentes ao Teste ELISA indireto Figure 3 - V alues of absorbance of bovine serum not reacting to the indirect E L ISA test 
Padronização e avaliação da sensibilidade e especificidade de um teste ELISA indireto para 0 diagnóstico da brucelose bovina utilizada como antígeno a cepa de B. abortus inativada

Percebe-se que o teste ELISA indireto, padronizado com 0 antígeno da B rucella abortus 1119/ 3 para Prova Lenta, consegue descriminar animais que foram expostos ao patógeno e com sorologia reagente nos testes de triagem dos animais não expostos e com sorologia não-reagente aos referidos testes, evidenciado na Figura 4.

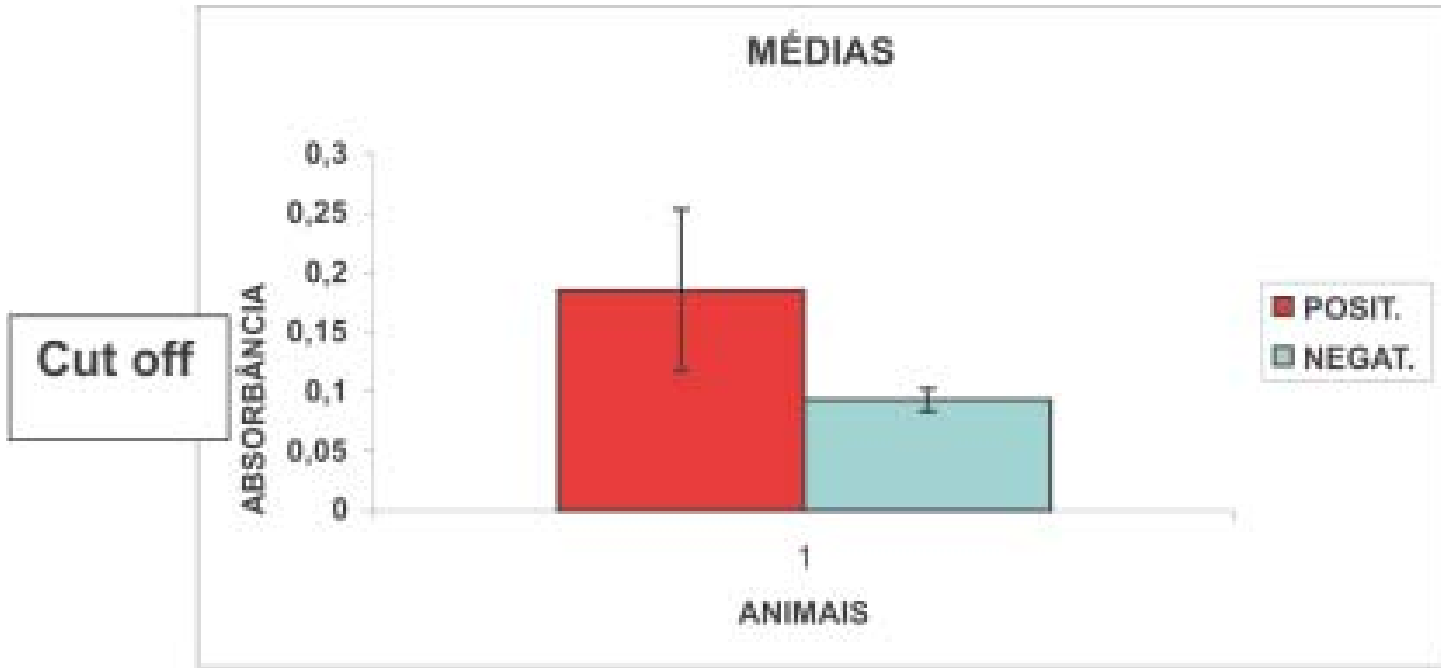

FIG URA 4 - Média das absorbâncias dos animais reagentes e não reagentes às técnicas de rotina para o diagnóstico da brucelose, submetidos ao Teste ELISA indireto

Figure 4 - A verage of reagents and not reagents animals to the routine techniques for brucellosis diagnosis submitted to the indirect E LISA test

O cálculo da concordância entre os testes foi verificado através da fórmula preconizada por Mathias et al. (1998), identificando-se valores em torno de 89\%. Com relação à sensibilidade e à especificidade entre os testes constatou-se os resultados, conforme apresentados na Q uadro 1:

\begin{tabular}{lcl}
\hline & Sensibilidade (\%) & Especificidade (\%) \\
\hline Elisa Indireto & 77,8 & 100 \\
Antígeno acidificado tamponado & 100 & $95 \mathrm{C} /$ relação 2-ME(G reve, 2007) \\
2- Mercaptoetanol & 88 & 100C/ relação AAT (G reve, 2007) \\
\hline
\end{tabular}

QUADRO 1 - Sensibilidade e especificidade dos testes de rotina comparado com teste ELISA indireto

Chart 1 - Sensitivity and specificity of the routine tests compared with indirect E L ISA test

\section{DISCUSSÃO}

Molnar et al. (2000) afirmam, após utilizar 3.338 amostras de soro, que o teste ELISA indireto apresentou superioridade em relação à fixação de complemento, pois no total de 626 soros positivos, somente o ELISA indireto confirmou a positividade em 249 amostras, e apenas 45 soros mostraram-se positivos no teste de fixação de complemento. O bserva-se, no presente experimento, que 0 teste ELISA se comporta com a mesma superioridade, diferenciando animais infectados reagentes no teste de animais não infectados. Com o objetivo de avaliar e comparar a prova de imunodifusão em gel de agarose utilizando extrato polissacarídico PO LI O , obtido da amostra B. abortus 1119-3 com as provas sorodiagnósticas convencionais para brucelose bovina, Megid et al. (2000) relataram que animais naturalmente infectados, com baixos títulos de anticorpos em provas como soro aglutinação lenta, 
fixação de complemento e ELISA, não apresentaram reação de precipitação na prova de imunodifusão. A pós avaliação de 273 soros de bovinos com histórico de brucelose, através da comparação entre o teste imunoenzimático competitivo empregando o conjunto preparado com soro policlonal com 0 teste de fixação de complemento, foram observados títulos de anticorpos em 32,93\% dos soros detectados pelo teste enzimático e 28,51\% no teste fixação de complemento, mostrando uma pequena superioridade do teste imunoenzimático (MATHIAS; MACMILLAN, 1995).

Jardim et al. (2006), com o intuito de avaliar o desempenho de dose reduzida da vacina B19 em rebanho bovino adulto, por meio de técnicas de diagnóstico sorológico, relataram resultados positivos distintos como $46,77 \%$ para a $\mathrm{FC}, 67,74 \%$ para o AAT, de $87,09 \%$ para a SAL com 2 -ME e de $100 \%$ para o ELISA indireto. Resultados semelhantes foram obtidos no presente trabalho, verificandose um poder de discriminação entre os animais não reagentes dos reagentes. Mathias et al. (1994), comparando resultados do teste imuno enzimático competitivo (TIEC), empregando como conjugado anticorpos monoclonais produzidos por dois clones de hibridomas, denominados de BM-38 e BM-40, preparados a partir da imunização de camundongos com Brucella melitensis 16M, foi observado que 0 TIEC, usando conjugado preparado com os anticorpos monoclonais BM-40, apresentou maior poder de discriminação que o mesmo teste usando o conjugado BM-38, identificando aimportância na padronização das fases de testes como este. Molnár et al. (2002), após fazerem um levantamento sorológico com amostras colhidas de 440 soros bubalinos compararam resultados obtidos de seis testes sorológicos e obtiveram sensibilidade e especificidade respectivamente de 100\% e 99,03\% no ELISA competitivo, 98,57\% e 97,33\% no ELISA indireto com conjugado antibovino de cadeia leve (anticorpo monoclonal), 97,14\% e 95,66\% no ELISA indireto com conjugado contra IgG bovino total, 91,42\% e 94\% no teste do antígeno acidificado tamponado e 79,28\% e 86,33\% na aglutinação rápida.

O s resultados do presente experimento foram semelhantes, pois a sensibilidade apresentada foi de 77,8\% e a especificidade de 100\%. Mathias et al. (1998), após avaliarem em bubalinos o teste de ensaio imunoenzimático competitivo (CEIA) e posterior comparação com resultados obtidos com 0 Teste Fixação de Complemento (CFT) e o Rosa de Bengala (RBT), os resultados mostraram concordância de 97,42\% entre o CEIA e o CFT e uma concordância de 95,39\% entre o CE IA e o RBT. A sensibilidade a e especificidade foram respectivamente de $100 \%$ e 98,55\%. O ELISA indireto desenvolvido nesse experimento apresentou uma sensibilidade discordante dos resultados obtidos no referido trabalho e uma especificidade com pequena diferença, demonstrando a superioridade do ELISA competitivo comparado ao ELISA indireto como preconizado pela literatura. Vanzini et al. (2001) utilizaram 31 amostras de leite obtido de 2 rebanhos com o intuito de comparar o teste ELISA indireto com 0 teste do anel de leite, obtendo diferentes diagnósticos. A titulação de 1:10 foi encontrada em 4 amostras e foi considerada negativa para o teste do anel de leite, porém foi positiva ao ELISA. As amostras positivas em ambos os testes apresentaram diferentes valores, a titulação do teste do anel de leite variou de 1:10 até 1:480, enquanto no ELISA variou de 1:10 até 1:3200. Erdenebaatar et al. (2003), com 0 objetivo de diferenciarem animais naturalmente infectados por Brucella spp. de Y. enterocolítica 09, antígenos foram extraídos da B. abortus cepa $544 \mathrm{com}$ n-lauroilsarcosina, sendo utilizado o teste imunoenzimático e testado a sua especificidade. 0 teste ELISA foi aplicado em 59 vacas, das quais 10 foram positivas para o antígeno acidificado tamponado, e 2 das 59 foram negativas para um ELISA utilizando extratos de sarcosina, sugerindo que ambas podem estar infectadas com Y . enterocolítica 09 e que o ELISA é uma prova capaz de diferenciar animais expostos a diferentes patógenos. Romero et al. (1995), com o objetivo de comparar PCR com ELISA utilizaram 56 amostras de leite positivas para 0 diagnóstico da brucelose bovina, das quais 49 amostras foram positivas para o PCR e apenas 1 amostra foi negativa para o ELISA, que apresentou sensibilidade de 98,2\% e especificidade de 100\%. AlonsoUrmeneta et al. (1998) investigaram se o epítopo, estrutura de lipopolissacarídeo O, é relevante para o ELISA indireto no diagnóstico da brucelose animal e se o teste precisa ser adaptado para vacas, cabras e ovelhas, além de avaliar também se o teste detecta anticorpos contra LPS. Nesse experimento verificase um bom desempenho com o antígeno utilizado, pois ele consegue detectar anticorpos contra LPS (lipopolissacarídeos) da linhagem de Brucella utilizada como antígeno. Contudo, faz-se necessário uma investigação mais apurada da interação Ag-Ac (antígeno-anticorpo), com o objetivo de se detectar

Rev. Acad., Ciênc. Agrár. Ambient., Curitiba, v. 6, n. 3, p. 361-370, jul./ set. 2008 
Padronização e avaliação da sensibilidade e especificidade de um teste ELISA indireto para 0 diagnóstico da brucelose bovina utilizada como antígeno a cepa de B. abortus inativada

anticorpos para B rucella abortus utilizando-se dois testes ELISA indiretos e dois testes E LISA competitivo e comparar com outros testes. A porcentagem de animais positivos no ELISA competitivo relativo ao teste Rosa de Bengala e fixação de complemento foi de 98,32\% e a porcentagem de animais negativos em vacas vacinadas com B. abortus 19 foi de 96,51\%.

\section{CONCLUSÃO}

As provas preconizadas pelo Programa Nacional de Controle e Erradicação da Brucelose e Tuberculose bovina são testes de fácil padronização nos laboratórios, baixo custo e com boa dinâmica no que se refere à sensibilidade e especificidade, mas faz-se necessário provas diagnósticas menos subjetivas.

0 presente trabalho demonstrou que o ELISA indireto pode ser utilizado na rotina de diagnóstico da enfermidade, uma vez que consegue diferenciar animais naturalmente infectados dos não infectados, contribuindo com formas de diagnóstico mais eficazes.

0 teste ELISA indireto, apesar de ser um teste que exige uma melhor infraestrutura do laboratório executor e de mão-de-obra especializada, consegue discriminar as amostras de animais infectados das de animais não infectados, além de possibilitar um maior número de amostras executadas.

Constatou-se especificidade em torno de 100\% e sensibilidade em torno de 77,8\%; observouse uma concordância entre os testes AAT e ELISA indireto de 89\%. O AAT prevalece como um teste de triagem por ser rápido, de baixo custo e alta sensibilidade comparado aos testes SAL e 2-ME.

\section{REFERÊNCIAS}

ALONSO-URMENETA, B. et al. Evaluation of lipopolysaccharides and polysaccharides of different epitopic structures in the indirect enzyme-linked immunosorbent assay for diagnosis of brucellosis in small ruminants and cattle. Clinical and Diagnostic Laboratory Immunology., v. 6, n. 6, p. 749754, 1998.

ERDENEBAATAR, J. et al. Enzyme-linked immunosorbent assay to differentiate the antibody responses of animals infected with Brucella species from those of animals infected with Yersinia enterocolitica O 9. Clinical and Diagnostic Laboratory Immunology., v. 10, n. 4, p. 710-714, 2003.

FREITAS, J. A. et al. Infecção brucélica em animais abatidos para consumo. 0 Biológico, v. 62, n. 1, p. $1-3,2000$.

FREY, A.; D I CANZIO, J.; ZURAKOWSK I, D. A. Statistically defined endpoint titer determination method for immunoassays. Journal of Immunology Methods., v. 221, n. 1-2, p. 35-41, 1998.

JARDIM, G. C. et al. Diagnóstico sorológico da brucelose bovina em animais adultos vacinados com dose reduzida da cepa 19 de Brucella abortus. Pesquisa Veterinária Brasileira, v. 26, n. 3, p. 177-182, 2006.

MATHIAS, L. A. et al. Avaliação de um teste imunoenzimático competitivo na diferenciação de anticorpos induzidos pela vacina B19, no diagnóstico sorológico da brucelose bovina. Pesquisa Veterinária Brasileira., v. 14, n. 1, p. 19-23, 1994.

Avaliação de um teste imunoenzimático competitivo no diagnóstico da brucelose em bưfalos (Bubalus Bubalis). Pesq. Vet. Bras., v. 18, n. 3/ 4, p. 111-114, 1998.

MATHIAS, L. A.; MACMILLAN, A. P.; Comparação de conjugados no teste imunoenzimático competitivo para o diagnóstico sorológico da brucelose bovina. Pesquisa Veterinária Brasileira., v. 15, n. 4, p. 101-105, 1995. 
MATHIAS, L. A.; MEIRELLES, R. B.; BUCHALA, F. G. Estabilidade do antígeno de célula total de Brucella abortus para uso no diagnóstico sorológico da brucelose bovina pela reação de fixação de complemento. Pesquisa Veterinária Brasileira., v. 27, n. 1, p. 18-22, 2007.

MEGID, J. et al. Avaliação das provas de soroaglutinação rápida, soroaglutinação lenta, antígeno acidificado, e 2-ME no diagnostico da brucelose bovina. Brazilian Journal of Veterinary Research and Animal Science., v. 37, n. 5, 2000.

MOLNÁR, E. et al. O corrência de brucelose bovina no estado do Pará confirmada por métodos sorológicos. Revista Brasileira de Medicina Veterinánia, v. 22, n. 3, p. 117-121, 2000.

MOLNÁR, L. et al. Avaliação de seis testes sorológicos no diagnóstico da brucelose bubalina. Pesquisa Veterinária Brasileira., v. 22, n. 2, p. 41-44, 2002.

ORTOLANI, E. L. et al. Acompanhamento sorológico de bovinos adultos vacinados com amostra B19. Teste de soroaglutinação lenta e 2-Mercaptoetanol. Arquivo Brasileiro de Medicina Veterinaria e Zootecnia, v. 39, n. 3, p. 377-386, 1987.

PESSEG UEIRO, P.; BARATA, C.; CORREIA, J. Brucelose - uma revisão Sistematizada. Medicina Interna, v. 10, n. 2, p. 91-100, 2003.

RIBEIRO, A. R. P. et al. Prevalência de tuberculose e brucelose bovina no município de Ilhéus. Arquivo Brasileiro de Medicina Veterinaria e Zootecnia., v. 55, n. 1, p. 120-122, 2003.

ROMERO, C. et al. Evaluation of PCR and indirect enzyme-linked immunosorbent assay on milk samples for diagnosis of brucellosis in dairy cattle. Journal of Clinical Microbiology., v. 33, n. 12, p. 3198-3200, 1995.

SILVA, F. L. et al. Brucelose bovina. Caderno Técnico de Veterinária e Zootecnia, v. 47, p. 112, 2005.

VANZINI, V. R. et al. Comparison of an indirect ELISA with the Brucella milk ring test for detection of antibodies to Brucella abortus in bulk milk samples. Veterinary Microbiology, v. 82, p. 55-60, 2001.

Recebido: 14/ 04/ 2008

Received: 04/ 14/ 2008

Aprovado: 23/ 04/ 2008

A pproved: 04/ 23/ 2008 